\title{
Research Article: Effect of temperature on life cycle of entomopathogenic nematode, Heterorhabditis indica poinar
}

\author{
AMIT U. PASCHAPUR, K. VIJAYALAKSHMI, B.S. SUNANDA AND \\ VINOD PAWAR
}

Article Chronicle: Received :

12.07.2017;

Accepted :

25.07.2017

KEY WoRDS:

Temperature on life

cycle,

Entomopathogenic nematode, Heterorhabditis indica, Poinar

Author for correspondence :

AMIT U. PASCHAPUR

Division of Entomology, ICAR-IARI, NEW DELHI, INDIA

Email : amitp3929@

gmail.com

See end of the article for authors' affiliations
SUMMARY : Experiment was conducted to study the effect of temperature on infection of host insect and time taken for emergence of IJs of $H$. indica from the cadavers of host insect (Galleria mellonella) under controlled laboratory conditions. The results indicated that the mean time taken by the nematode to cause infection in the host insect was significantly less at three temperatures, viz., $30^{\circ} \mathrm{C}$, room temperature $\left(25-28^{\circ} \mathrm{C}\right)$ and ambient atmospheric temperature $\left(23-34^{\circ} \mathrm{C}\right)$ which ranged from $24-30$ hours. At $20^{\circ} \mathrm{C}$ temperature, the infection occurred after $44 \mathrm{hrs}$ of inoculation, indicating the maximum time required for $\mathrm{H}$. indica to cause infection. At test temperatures of $10^{\circ} \mathrm{C}$ and $40^{\circ} \mathrm{C}$ nematode did not cause the infection to the host insect due to lethal high and lethal low temperature effects. From the results it was evident that at ambient atmospheric temperature $\left(23-34^{\circ} \mathrm{C}\right)$, the mean time taken for emergence of IJs was $226 \mathrm{hrs}$ (9.42 days). While, the mean time taken for emergence at $30^{\circ} \mathrm{C}$ and room temperature (25$28^{\circ} \mathrm{C}$ ) were $236 \mathrm{hrs}$ (9.83 days) and $246 \mathrm{hrs}$ ( 10.25 days), respectively. The mean time taken for emergence at $20^{\circ} \mathrm{C}$, was $286 \mathrm{hrs}$ (11.92 days) and all the above treatments were significantly on par with each other.

How to cite this article : Paschapur, Amit. U., Vijayalakshmi, K., Sunanda, B. S. and Pawar, Vinod (2017). Effect of temperature on life cycle of entomopathogenic nematode, Heterorhabditis Indica poinar. Agric. Update, 12(TECHSEAR-2) : 578-582; DOI: 10.15740/HAS/AU/12.TECHSEAR(2)2017/578-582. 